\title{
Partitioning of microbial biomass in pelagic aquatic communities: maximum resiliency as a food web organizing construct
}

\author{
Edward A. Laws* \\ University of Hawaii, Department of Oceanography, 1000 Pope Road, Honolulu, Hawaii 96822, USA
}

\begin{abstract}
Application of the principle of maximum resiliency to a pelagic food web model leads to the conclusion that the ratio of heterotrophic bacterial biomass to phytoplankton biomass is greatest under oligotrophic conditions. This prediction is in accord with the results of several field studies. Under eutrophic conditions, model results indicate that the same ratio is positively correlated with temperature, and that microbial biomass is dominated by phytoplankton at low temperatures and high production rates. Predictions of heterotrophic bacterial biomass based on the model and information on temperature and photosynthetic rates or phytoplankton biomass are in excellent agreement with field data from a wide variety of limnetic and marine habitats with depths $\geq 6 \mathrm{~m}$. The model consistently underestimated heterotrophic bacterial biomass in systems impacted by riverine throughput and in hypereutrophic systems in which the euphotic zone was less than $3 \mathrm{~m}$ deep. In systems less than 3 to $4 \mathrm{~m}$ deep the model was less successful in predicting heterotrophic bacterial biomass than in deeper systems, although there was no apparent bias in the results. Because of the short generation time of aquatic microbes, pelagic food web behavior that is determined primarily by the activity of these organisms may tend to display characteristics expected of the mature stages of ecological succession. Maximum resiliency, a characteristic expected of such mature stages, may therefore prove to be a useful construct in modeling the response of pelagic food webs to environmental change.
\end{abstract}

KEY WORDS: Bacteria $\cdot$ Model $\cdot$ Food web $\cdot$ Stability $\cdot$ Phytoplankton

Resale or republication not permitted without written consent of the publisher

\section{INTRODUCTION}

Ecologists have hypothesized for many years that the evolution of biological systems is driven by fundamental principles or forces. Lotka (1922), for example, argued that natural selection tended to maximize the energy flux through a system, at least insofar as this was compatible with the constraints to which the system was subject. Odum (1983) expanded on Lotka's ideas. He argued that systems that prevail develop designs that maximize the flow of useful energy. 'They maximize power, and theories and corollaries derived from the maximum power principle explain much about the structure and processes of systems' (Odum 1983, p. 6). Odum's ideas have been sharply criticized by some authors. Fenchel (1987, p. 17), for example, argued that Odum's approach, 'had an appeal for some time, I suppose, only because it was sufficiently obscure and incomprehensible to appear profound.' In reacting to such comments, Patten (1993) observed, 'The admissibility of virtually any system configuration, within given physical and resource constraints, does not mean the processes of ecosystem organization are lawless. The challenge is to find the laws, and that is the central thrust of Odum's work.'

Recently Cropp \& Gabric (2002) used a genetic algorithm to simulate the adaptation of the biota in a simple linear food chain consisting of a limiting nutrient, autotrophs, and heterotrophs. Four basic selection pressures were formulated by considering thermodynamic (entropy, exergy, and ascendancy) and ecological (sustainable biomass, primary productivity, and productivity per unit biomass) imperatives that influence ecosystems. Interestingly, their simulations suggested that, within the constraints of the external environment and the genetic potential of their con- 
stituent biota, ecosystems evolve to the state most resilient to perturbation.

The words 'most resilient to perturbation' here mean that, following a small perturbation, the system returns to its equilibrium configuration most rapidly. The rate of return to equilibrium is determined by the real parts of the eigenvalues of the so-called community matrix, whose elements consist of partial derivatives of the deterministic equations describing the temporal dynamics of the system evaluated at the equilibrium point. The more negative the real part of the least negative eigenvalue, the more rapidly the system returns to equilibrium. May (1974) provides a lucid discussion of these topics. Laws et al. (2000) applied the assumption of maximum resiliency to the more complex pelagic food web depicted in Fig. 1. All but 2 parameters in the model were assigned values based on deterministic equations. Two independent adaptive characteristics of the model, the relative growth rates of the large phytoplankton and the biomass of filter feeders, were assigned values that maximized the resiliency of the steady-state system to perturbations at the given temperature and photosynthetic rate. The predictions of the model with respect to the behavior of the export ratio (Downs 1989, Murray et al. 1989), phytoplankton biomass, and heterotrophic bacterial biomass were in remarkable agreement with field observations encompassing a broad range of environmental conditions.

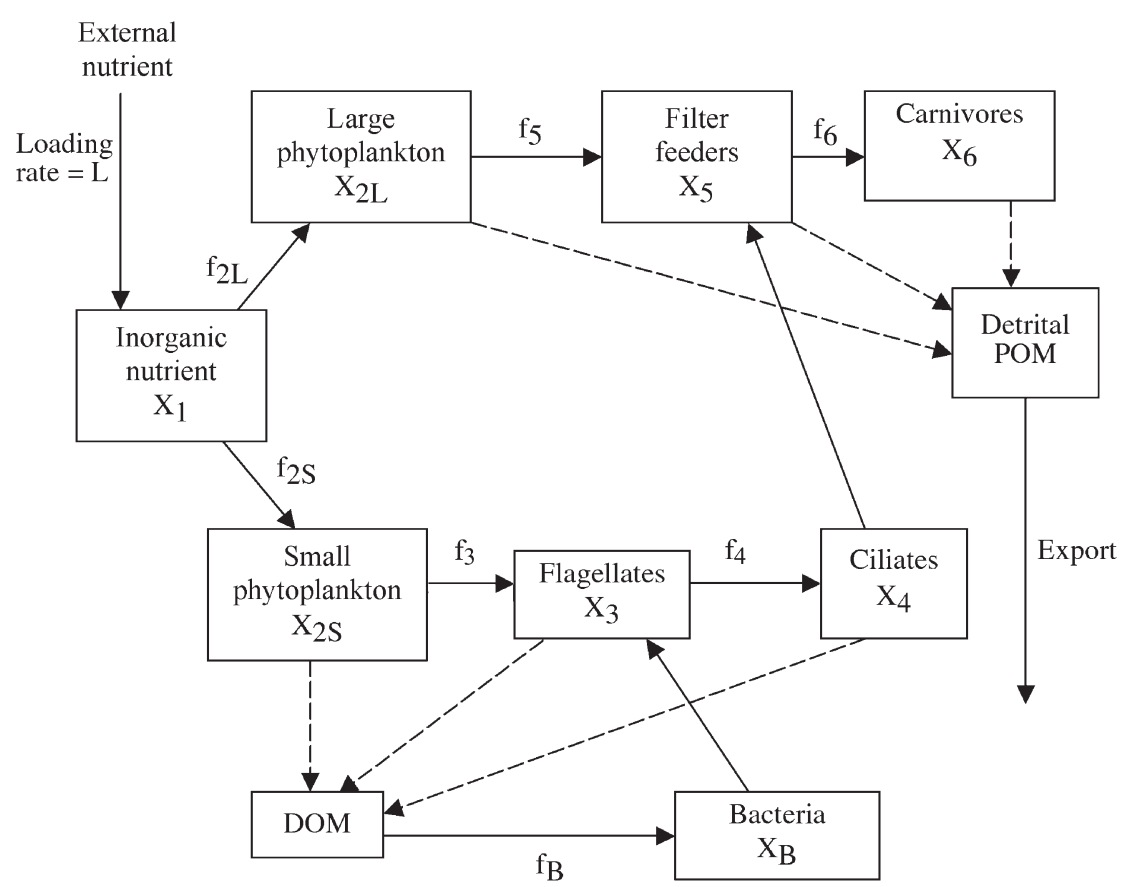

Fig. 1. Feeding and excretion relationships in a model pelagic food web in which photosynthetic production is partitioned between small and large phytoplankton cells (Laws et al. 2000). f: fluxes between boxes associated with nutrient uptake or grazing; dashed arrows: excretion; solid arrows: nutrient uptake or grazing
According to the model, photosynthetic rate and temperature are the primary determinants of community composition and system behavior.

Several authors have commented on the patterns of heterotrophic and autotrophic biomass in aquatic systems (Pomeroy \& Deibel 1986, Li et al. 1992, Simon et al. 1992, Legendre \& Rassoulzadegan 1995, Gasol et al. 1997, Biddanda et al. 2001, Cotner \& Biddanda 2002). Empirically one observes that the ratio of heterotrophic bacterial biomass to microalgal biomass decreases as systems become more eutrophic (Li et al. 1992, Simon et al. 1992, Gasol et al. 1997, Biddanda et al. 2001, Cotner \& Biddanda 2002). Biddanda et al. (2001) commented (p. 732), 'The underlying cause of this relationship is unclear.' They suggested 2 possible explanations: (1) heterotrophic bacteria are selectively grazed by bacterivores at the eutrophic end of the gradient, and (2) heterotrophic bacteria are better able to acquire nutrients at low ambient concentrations in oligotrophic systems. Pomeroy \& Deibel (1986) have also noted that the ratio of heterotrophy to autotrophy is positively correlated with temperature. They argued that this pattern was due to differences in the temperature dependence of photosynthesis and respiration.

Fig. 2 shows the ratio of heterotrophic bacterial biomass to phytoplankton biomass predicted from the model of Laws et al. (2000), with temperature and photosynthetic rate as the independent variables. In accordance with the observations of $\mathrm{Li}$ et al. (1992), Simon et al. (1992), Gasol et al. (1997), and Biddanda et al. (2001), the ratio of heterotrophic bacterial biomass to phytoplankton biomass is highest in oligotrophic systems. The ratio is relatively insensitive to temperature in oligotrophic systems, but is strongly and positively correlated with temperature in eutrophic systems, consistent with the observations of Pomeroy \& Deibel (1986). Laws et al. (2000) found that predicted and observed heterotrophic bacterial biomass were in excellent agreement in 10 marine ecosystems ranging from the equatorial Pacific to the Ross Sea and Greenland polynya.

\section{METHODS}

In order to more rigorously test the predictions of the Laws et al. (2000) model relative to the role of bacteria in aquatic ecosystems, I have examined data on bacterial biomass, phyto- 
plankton production and/or biomass, and temperature from a wide variety of freshwater and marine ecosystems. The data set includes results from a total of 39 studies, 8 in freshwater and 31 in marine systems (Table 1). The data are taken primarily from results reported in the last $10 \mathrm{yr}$, although a few of the results analyzed by Laws et al. (2000) were reported as long as 15 yr ago. Although Fig. 2 treats temperature and photosynthetic rate as the independent variables in the model, the latter is less frequently reported than the concentration of chlorophyll $a$ (chl a). Because the model predicts a one-to-one relationship between photosynthetic rate and phytoplankton carbon, I treated phytoplankton carbon and temperature as independent variables and used these to predict heterotrophic bacterial carbon $\left(\mathrm{C}_{\mathrm{HB}}\right)$ from the

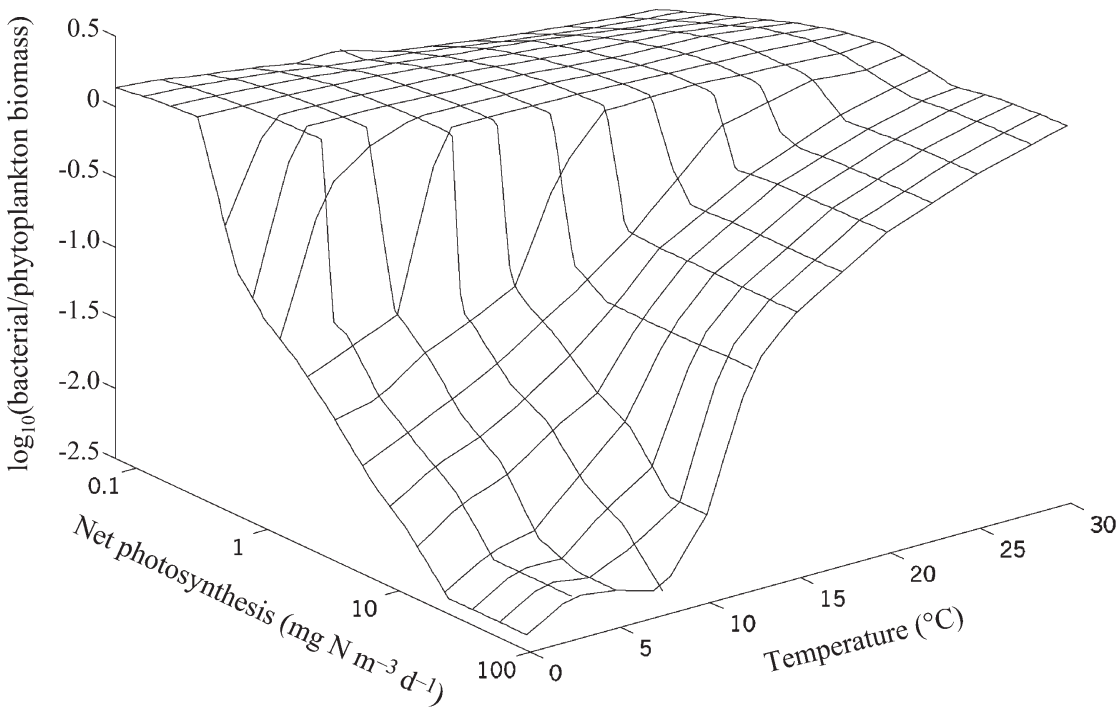

Fig. 2. Ratio of heterotrophic bacterial biomass to phytoplankton biomass as a function of photosynthetic rate and temperature for the pelagic food web model shown in Fig. 1. Adjustable parameters were chosen to produce a steady state with maximum resiliency output of the model in cases where photosynthetic rates were not reported. I excluded studies in shallow systems (depth $<5 \mathrm{~m}$ ) from the initial analysis, since the Laws et al. (2000) model envisions a strictly pelagic ecosystem. This fact accounts for the relatively small number of freshwater systems included in the data set. The depths of the freshwater systems ranged from 5.9 to $100 \mathrm{~m}$. I also excluded hypereutrophic systems having chl a concentrations $>100 \mathrm{mg} \mathrm{m}^{-3}$ from the initial analysis, since the Laws et al. (2000) model assumes nutrient limitation.

Since the model predicts phytoplankton and heterotrophic bacterial biomass in terms of carbon, it was necessary to convert heterotrophic bacterial cell counts and/or cell volume and chl a concentrations to carbon equivalents. In cases where only data on heterotrophic bacterial cell counts were reported by the authors, I assumed a carbon content of $12 \mathrm{fg} \mathrm{cell}^{-1}$ for open ocean bacteria and $30 \mathrm{fg} \mathrm{cell}^{-1}$ for coastal, estuarine, and limnetic bacteria (Fukuda et al. 1998). To convert chl a concentrations to phytoplankton carbon, I assumed a C:chl a ratio of 50 by weight (Fuhrman et al. 1985, Chróst et al. 1989, Cho \& Azam 1990).

\section{RESULTS}

I found a high degree of correlation between $\mathrm{C}_{\mathrm{HB}}$ predicted by the model and $\mathrm{C}_{\mathrm{HB}}$ estimated from field data (Fig. 3). The model accounts for $84 \%$ of the variance in the log-transformed data, which span almost 2 orders of magnitude in $\mathrm{C}_{\mathrm{HB}}$. A total of $67 \%$ of the data lie within a factor of 1.6 of the 1:1 line, i.e. heterotrophic bacterial biomass can be predicted to within a factor of \pm 1.6 by the model. There was no systematic difference in the predictions of the model for marine and limnetic systems, but $\mathrm{C}_{\mathrm{HB}}$ was predicted more accurately when photosynthetic rate and temperature were the independent variables $(r=0.96)$ versus phytoplankton carbon and temperature $(\mathrm{r}=0.78)$.

Following this analysis, I examined the ability of the model to predict $\mathrm{C}_{\mathrm{HB}}$ in 3 types of aquatic systems that do not, strictly speaking, conform to the assumptions of the model. In 3 hypereutrophic lakes (Table 2), $\mathrm{C}_{\mathrm{HB}}$ was much less than the model predictions based on chl a concentrations. In the one case where both chl a concentrations and photosynthetic rates were reported, the discrepancy was greatly reduced when photosynthetic rate and temperature were the independent variables in the model. In shallow (mean depth 1.1 to $3.6 \mathrm{~m}$ ) ecosystems (Fig. 4), the 3 lowest and 4 highest predicted $\mathrm{C}_{\mathrm{HB}}$ values lay below and above the 1:1 line, respectively. Given the small number of data points, it is hard to say whether this pattern represents a systematic bias. There is certainly more scatter in the data, the standard deviation of the log-transformed data being twice as large in Fig. 4 compared to Fig. 3. Finally, in systems impacted by river throughput (Table 3), the predictions of the model were consistently higher than the observed $\mathrm{C}_{\mathrm{HB}}$. The discrepancy was most pronounced in the case of inner shelf waters off the mouth of the Yangtze River, PR China. 
Table 1. Characteristics of aquatic systems in which heterotrophic bacterial carbon $\left(\mathrm{C}_{\mathrm{HB}}\right)$ was estimated using the model of Laws et al. (2000). $\mathrm{C}_{\mathrm{HB}}$ estimated using (A) temperature and photosynthetic rate or (B) temperature and phytoplankton carbon as independent variables. BATS: Bermuda Atlantic Time Series; NABE: North Atlantic Bloom Experiment

\begin{tabular}{|c|c|c|c|c|}
\hline $\begin{array}{l}\text { (A) } \\
\text { Body of water (temperature) }\end{array}$ & $\begin{array}{l}\text { Photosynthetic } \\
\text { rate } \\
\left(\mathrm{mg} \mathrm{C} \mathrm{m}^{-3} \mathrm{~d}^{-1}\right)\end{array}$ & $\begin{array}{c}\mathrm{C}_{\mathrm{HB}} \\
\left(\mathrm{mg} \mathrm{m}^{-3}\right)\end{array}$ & $\begin{array}{l}\text { Predicted } \mathrm{C}_{\mathrm{HB}} \text { based on } \\
\text { temperature and photo- } \\
\text { synthetic rate }\left(\mathrm{mg} \mathrm{m}^{-3}\right)\end{array}$ & Source \\
\hline N. Atlantic, Canary Islands, Zone A $\left(20^{\circ} \mathrm{C}\right)$ & 2.5 & 4.6 & 4.8 & Bode et al. (2001) \\
\hline N. Atlantic, Canary Islands, Zone B $\left(20^{\circ} \mathrm{C}\right)$ & 1.7 & 4.4 & 3.1 & Bode et al. (2001) \\
\hline N. Atlantic, Canary Islands, Zone C $\left(20^{\circ} \mathrm{C}\right)$ & 2.7 & 5.4 & 5.3 & Bode et al. (2001) \\
\hline Sargasso Sea, BATS $\left(21^{\circ} \mathrm{C}\right)$ & 3.3 & 2.2 & 4.1 & Carlson et al. (1998) \\
\hline Ross Sea, Antarctica $\left(0^{\circ} \mathrm{C}\right)$ & 34.5 & 11 & 9.6 & Carlson et al. (1998) \\
\hline Lawrence Lake, MI, USA $\left(21^{\circ} \mathrm{C}\right)$ & 41 & 72 & 53.5 & Coveney \& Wetzel (1995) \\
\hline North Atlantic, NABE $\left(12.5^{\circ} \mathrm{C}\right)$ & 31.5 & 20 & 23.1 & Ducklow et al. (1993) \\
\hline Equatorial Pacific, La Niña $\left(24^{\circ} \mathrm{C}\right)$ & 12.3 & 12 & 13 & Ducklow et al. (1995) \\
\hline Equatorial Pacific, El Niño $\left(27^{\circ} \mathrm{C}\right)$ & 8.0 & 10 & 7.3 & Ducklow et al. (1995) \\
\hline Arabian Sea $\left(25^{\circ} \mathrm{C}\right)$ & 17 & 19.6 & 16.7 & Ducklow et al. (2000) \\
\hline Strait of Georgia $\left(17.3^{\circ} \mathrm{C}\right)$ & 190 & 183 & 231 & Harrison et al. (1991) \\
\hline N. Pacific, Stn ALOHA $\left(25^{\circ} \mathrm{C}\right)$ & 3.1 & 3.9 & 3.1 & Karl \& Dobbs (1998) \\
\hline Subarctic Pacific, Stn Papa $\left(6^{\circ} \mathrm{C}\right)$ & 8 & 14.2 & 22.7 & Kirchman et al. (1993) \\
\hline $\begin{array}{l}\text { Unnamed lake, Ziegler Island, } \\
\text { Franz Joseph Land }\left(1.5^{\circ} \mathrm{C}\right)\end{array}$ & 22 & 14 & 10 & Panzenböck et al. (2000) \\
\hline North Sea, Transect 1, May $1992\left(9^{\circ} \mathrm{C}\right)$ & 12.3 & 38.7 & 23.1 & Richardson et al. (1998) \\
\hline North Sea, Transect $2\left(9.5^{\circ} \mathrm{C}\right)$ & 9.0 & 39.7 & 34.9 & Richardson et al. (1998) \\
\hline North Sea, Transect $3\left(10^{\circ} \mathrm{C}\right)$ & 9.1 & 59.8 & 33.4 & Richardson et al. (1998) \\
\hline North Sea, Transect 1, August $1991\left(12^{\circ} \mathrm{C}\right)$ & 13.8 & 26.9 & 28.9 & Richardson et al. (1998) \\
\hline East China Sea, mid-shelf $\left(27^{\circ} \mathrm{C}\right)$ & 6.5 & 3.5 & 7.9 & Shiah et al. (2001) \\
\hline East China Sea, outer-shelf $\left(29^{\circ} \mathrm{C}\right)$ & 3.2 & 3.2 & 3.3 & Shiah et al. (2001) \\
\hline Lake Constance, Germany $\left(13.4^{\circ} \mathrm{C}\right)$ & 72 & 95 & 62.9 & Simon et al. (1998) \\
\hline Peru upwelling system $\left(16.8^{\circ} \mathrm{C}\right)$ & 179 & 126 & 163 & Sorokin \& Kogelschatz (1979) \\
\hline Greenland polynya $\left(0^{\circ} \mathrm{C}\right)$ & 7.2 & 7.2 & 7.8 & Yager (1996) \\
\hline $\begin{array}{l}\text { (B) } \\
\text { Body of water (temperature) }\end{array}$ & $\begin{array}{l}\text { hytoplankton } \\
\text { carbon } \\
\left(\mathrm{mg} \mathrm{C} \mathrm{m}^{-3}\right)\end{array}$ & $\begin{array}{c}\mathrm{C}_{\mathrm{HB}} \\
\left(\mathrm{mg} \mathrm{m}^{-3}\right)\end{array}$ & $\begin{array}{c}\text { Predicted } \mathrm{C}_{\mathrm{HB}} \text { based on } \\
\text { temperature and phyto- } \\
\text { plankton carbon }\left(\mathrm{mg} \mathrm{m}^{-3}\right)\end{array}$ & Source \\
\hline Menai Bridge, North Wales, UK $\left(12^{\circ} \mathrm{C}\right)$ & 250 & 60 & 26.2 & Blight et al. (1995) \\
\hline Lake Plußsee, Germany $\left(7^{\circ} \mathrm{C}\right)$ & 1975 & 25.3 & 24.8 & Chróst et al. (1989) \\
\hline Eagle Mountain Lake, TX, USA $\left(18.5^{\circ} \mathrm{C}\right)$ & 875 & 120 & 390 & Chrzanowski \& Grover (2001) \\
\hline Joe Pool Lake, TX, USA $\left(18.5^{\circ} \mathrm{C}\right)$ & 250 & 105 & 109 & Chrzanowski \& Grover (2001) \\
\hline $\begin{array}{l}\text { Ria de Aveiro, Portugal, Stns N1 } \\
\text { and I2 }\left(19.6^{\circ} \mathrm{C}\right)\end{array}$ & 425 & 123 & 226 & Cunha et al. (2000) \\
\hline Delaware Estuary, upper region $\left(15^{\circ} \mathrm{C}\right)$ & 560 & 90 & 132 & Hoch \& Kirchman (1993) \\
\hline Delaware Estuary, middle region $\left(15^{\circ} \mathrm{C}\right)$ & 750 & 99 & 177 & Hoch \& Kirchman (1993) \\
\hline Delaware Estuary, lower region $\left(15^{\circ} \mathrm{C}\right)$ & 540 & 111 & 128 & Hoch \& Kirchman (1993) \\
\hline Maliakos Gulf, Greece, Inner Gulf $\left(19^{\circ} \mathrm{C}\right)$ & 62.5 & 30 & 31 & Kormas et al. (1998) \\
\hline Maliakos Gulf, Greece, Middle Gulf $\left(19^{\circ} \mathrm{C}\right)$ & 50 & 11.3 & 28.7 & Kormas et al. (1998) \\
\hline Maliakos Gulf, Greece, Outer Gulf $\left(19^{\circ} \mathrm{C}\right)$ & 25 & 9 & 22 & Kormas et al. (1998) \\
\hline Crooked Lake, Antarctica $\left(1.2^{\circ} \mathrm{C}\right)$ & 15 & 6.4 & 13.8 & Laybourn-Parry et al. (1992) \\
\hline English Channel $\left(12^{\circ} \mathrm{C}\right)$ & 100 & 20 & 19.3 & Rodríguez et al. (2000) \\
\hline St. Lawrence estuary $\left(4.7^{\circ} \mathrm{C}\right)$ & 160 & 44 & 12 & Sime-Ngando et al. (1995) \\
\hline Piburger See, Austria $\left(12.3^{\circ} \mathrm{C}\right)$ & 150 & 48 & 21 & Sommaruga \& Psenner (1995) \\
\hline Ría de Vigo, Spain $\left(15^{\circ} \mathrm{C}\right)$ & 175 & 100 & 41.6 & Zdanowski \& Figueiras (1997) \\
\hline
\end{tabular}

\section{DISCUSSION}

At least some of the variance of the relationship between observed and predicted $\mathrm{C}_{\mathrm{HB}}$ can be attributed to uncertainty in the factors used to convert chl $a$ and cell counts to carbon. Phytoplankton C:chl a ratios depend on a variety of factors, including temperature, irradiance, species composition, and nutritional status
(Shuter 1979, Chan 1980). C:chl a ratios reported from field work have ranged between roughly 20 and 125 by weight (Sakshaug \& Holm-Hansen 1986, DiTullio \& Smith 1996, Smith et al. 1996, Karl \& Dobbs 1998). Assuming a C:chl a ratio of 50 by weight is a reasonable approximation but could produce errors of as much as a factor of $\sim 2$. This fact probably accounts for the poorer correlation between the model and field 
Table 2. Heterotrophic bacterial biomass in hypereutrophic lakes estimated using the Laws et al. (2000) model

\begin{tabular}{|c|c|c|c|c|c|c|}
\hline Lake (temperature) & $\begin{array}{c}\mathrm{Chl} \mathrm{a} \\
\left(\mathrm{mg} \mathrm{m}^{-3}\right)\end{array}$ & $\begin{array}{c}\text { Photosynthetic } \\
\text { rate } \\
\left(\mathrm{mg} \mathrm{C} \mathrm{m}^{-3} \mathrm{~d}^{-1}\right)\end{array}$ & $\begin{array}{c}\mathrm{C}_{\mathrm{HB}} \\
\left(\mathrm{mg} \mathrm{m}^{-3}\right)\end{array}$ & $\begin{array}{c}\text { Predicted } \mathrm{C}_{\mathrm{HB}} \\
\text { based on } \\
\text { chl } a \\
\left(\mathrm{mg} \mathrm{m}^{-3}\right)\end{array}$ & $\begin{array}{l}\text { Predicted } \mathrm{C}_{\mathrm{HB}} \\
\text { based on } \\
\text { photosynthetic } \\
\text { rate }\left(\mathrm{mg} \mathrm{m}^{-3}\right)\end{array}$ & Source \\
\hline Lake Rodó, Uruguay $\left(18.9^{\circ} \mathrm{C}\right)$ & 223 & & 210 & 4956 & & Sommaruga (1995) \\
\hline Lake Kauhak, Molokai $\left(24.5^{\circ} \mathrm{C}\right)$ & 105 & & 105 & 5396 & & Donachie et al. (1999) \\
\hline Lake Nesjøvatn, Norway $\left(16^{\circ} \mathrm{C}\right)$ & 232 & 330 & 66 & 3204 & 376 & Vadstein et al. (1988) \\
\hline
\end{tabular}

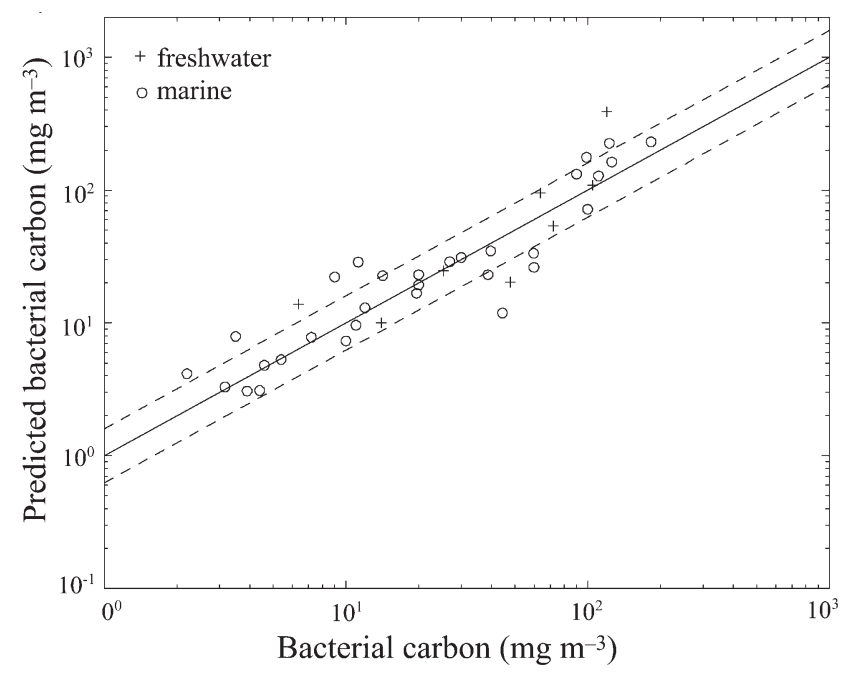

Fig. 3. Relationship between measured and predicted heterotrophic bacterial carbon $\left(\mathrm{C}_{\mathrm{HB}}\right)$ from the systems in Table 1. The straight line is the 1:1 line. Dashed lines are \pm 1 SD from the 1:1 line

results when chl $a$ and temperature are the independent variables.

Fukuda et al. (1998) have pointed out that the use of $20 \mathrm{fg} \mathrm{C}_{\text {cell }}{ }^{-1}$ (Pedrós-Alió \& Brock 1982, Fuhrman et al. 1985, Hessen 1985) as a conversion factor between cell counts and $\mathrm{C}_{\mathrm{HB}}$ can lead to an overestimation of $\mathrm{C}_{\mathrm{HB}}$ by as much as $330 \%$ in open oceans and an underestimation by as much as $40 \%$ in coastal environments. My use of different conversion factors for open ocean

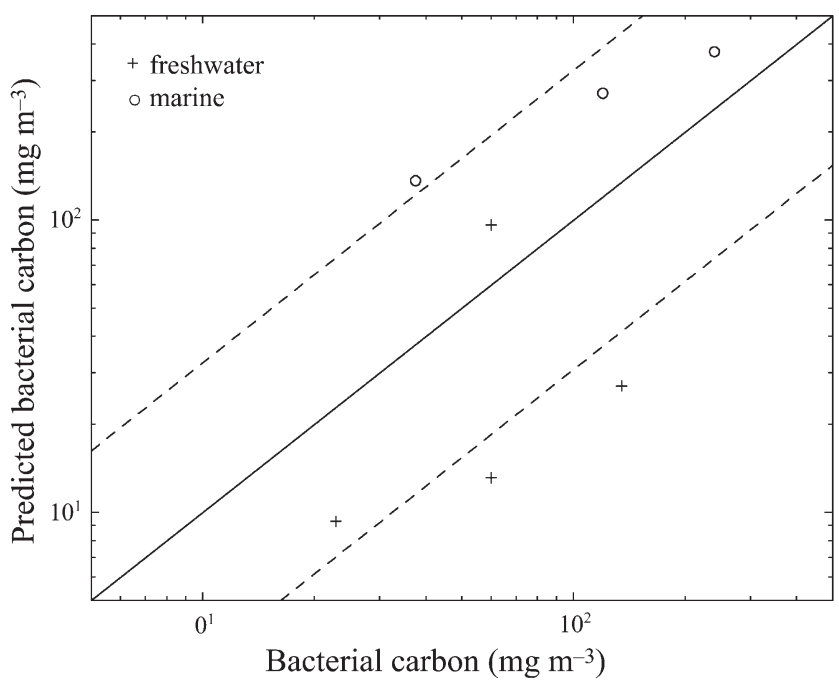

Fig. 4. Relationship between measured and predicted $\mathrm{C}_{\mathrm{HB}}$ for shallow systems (freshwater: Butler et al. 2000, Kisand \& Tammert 2000, Revilla et al. 2000, Vörös et al. 1996; marine: Reitner et al. 1997). The straight line is the 1:1 line. Dashed lines are \pm 1 SD from the 1:1 line

and coastal/limnetic systems has probably reduced the level of noise caused by uncertainty in this factor, but it seems fair to say that the abscissa in Fig. 3 is associated with a nontrivial amount of noise.

Estimates of photosynthetic rates are also subject to error, both from measurement error and natural variability. Most reported estimates of photosynthetic rates are based on the ${ }^{14} \mathrm{C}$ method originally developed by Steemann Nielsen (1952). Still, 50 yr later, there is

Table 3. Heterotrophic bacterial biomass in shallow/riverine eutrophic systems estimated using the Laws et al. (2000) model

\begin{tabular}{|lcccc|}
\hline System (temperature) & $\begin{array}{c}\mathrm{Chl} \mathrm{a} \\
\left(\mathrm{mg} \mathrm{m}^{-3}\right)\end{array}$ & $\begin{array}{c}\mathrm{C}_{\mathrm{HB}} \\
\left(\mathrm{mg} \mathrm{m}^{-3}\right)\end{array}$ & $\begin{array}{c}\text { Predicted } \mathrm{C}_{\mathrm{HB}} \text { based } \\
\text { on chl } a\left(\mathrm{mg} \mathrm{m}^{-3}\right)\end{array}$ & Source \\
\hline Ria de Aveiro, Stn I4 $\left(22.7^{\circ} \mathrm{C}\right)$ & 17 & 157 & 671 & Cunha et al. (2000) \\
Ria de Aveiro, Stn I6 $\left(22.7^{\circ} \mathrm{C}\right)$ & 19 & 189 & 748 & Cunha et al. (2000) \\
Ria de Aveiro, Stn I8 $\left(25.2^{\circ} \mathrm{C}\right)$ & 26.5 & 256 & 1379 & Cunha et al. (2000) \\
Ria de Aveiro, Stn Rio Boco $\left(25.7^{\circ} \mathrm{C}\right)$ & 27.6 & 255 & 1502 & Cunha et al. (2000) \\
Yangtze River estuary, inner shelf $\left(21^{\circ} \mathrm{C}\right)$ & 3.93 & 7.1 & 123 & Shiah et al. (2001) \\
\hline
\end{tabular}


uncertainty over exactly what the ${ }^{14} \mathrm{C}$ method measures (Marra 2002). Even if photosynthetic measurements could be made with no analytical error, rates vary naturally over space and time, and any set of discrete measurements will therefore be subject to error when integrated over space and time. Finally, temperature also varies with space and time, and in temperate and polar ecosystems, the range of temperature over the course of a year can easily be $20^{\circ} \mathrm{C}$ (Sommaruga \& Psenner 1995).

The model itself (Fig. 1) is a considerable simplification of the interactions in a pelagic food web, and the assumption of steady state is clearly an approximation that in some cases may be reasonable only when system behavior is integrated over appropriate time and space scales.

Considering the various sources of error in the data and model, the level of noise evident in Fig. 3 seems not unreasonable. The assumption of maximum resiliency leads to predicted system behavior that explains much of the variability of $\mathrm{C}_{\mathrm{HB}}$ across a wide range of pelagic aquatic ecosystems. The limitations of the model are apparent in Tables $2 \& 3$ and Fig. 4. In the 3 hypereutrophic lakes the concentrations of heterotrophic bacterial carbon estimated using the model with temperature and chl $a$ as independent variables are 20 to 50 times higher than the observed $\mathrm{C}_{\mathrm{HB}}$. Some of this discrepancy may be attributed to the fact that in these systems the concentration of phytoplankton carbon estimated using an assumed C:chl a ratio of 50 is undoubtedly too high. However, it is unlikely that the true C:chl a ratio is much less than 20. Reducing the assumed C:chl a ratio from 50 to 20 reduces the predicted $\mathrm{C}_{\mathrm{HB}}$ by a roughly proportionate amount, i.e. much less than the factor of 20 to 50 discrepancy. For Lake Nesjøvatn, central Norway, photosynthetic rates were reported along with chl a concentrations. When $\mathrm{C}_{\mathrm{HB}}$ is predicted using temperature and photosynthetic rate as the independent variables, the discrepancy between observed and predicted $\mathrm{C}_{\mathrm{HB}}$ is reduced by almost an order of magnitude. In this case at least, the predictions of the model appear much more robust when photosynthetic rate is substituted for phytoplankton biomass as the second independent variable. The implication is that $\mathrm{C}_{\mathrm{HB}}$ is determined primarily by the activity and not the biomass of the phytoplankton. However, there is still a 5.6-fold discrepancy between observed and predicted $\mathrm{C}_{\mathrm{HB}}$, which is about 3 times the standard deviation of the data in Fig. 3.

The average spectral extinction coefficient of chl a and associated pigments is about $0.016 \mathrm{~m}^{2} \mathrm{mg}^{-1} \mathrm{chl} \mathrm{a}$ (Bannister 1974). At chl a concentrations of 100 to $200 \mathrm{mg} \mathrm{m}^{-3}$ (Table 2), the $1 \%$ light level occurs at depths of $\sim 1.5$ to $3.0 \mathrm{~m}$. In such turbid systems photosynthetic rates are limited primarily by light rather than nutrients. The implication of the results in Fig. 3 and Table 2 is that the relationship between phytoplankton activity and $\mathrm{C}_{\mathrm{HB}}$ is fundamentally different in nutrient- and light-limited systems. This difference may reflect the tendency of photosynthate to be released as dissolved organic carbon in the former and to accumulate as particulate organic carbon in the latter (Carlson \& Ducklow 1996, Carlson et al. 1998, Biddanda et al. 2001). The model (Fig. 1) accounts for this behavior by routing more photosynthate through the microbial loop, but this is apparently insufficient to explain the difference between the behavior of nutrient- and light-limited food webs.

Except under hypereutrophic conditions, the metabolism of shallow aquatic ecosystems is dominated by benthic processes (Scheffer 2001). In such systems, the interaction between the benthos and water column can have a major impact on the composition of the planktonic community (Scheffer 1999). Benthic filter feeders, in particular, can structure the plankton through topdown control, and benthic larvae may contribute substantially to the biomass of the planktonic community. The release of nutrients associated with benthic respiratory activity can be a major source of nutrient loading to the water column. While it is fair to say that the benthic community competes with the pelagic community for resources (Scheffer et al. 2000) and reduces its overall biomass, it is not obvious from the foregoing considerations that the existence of the benthos would systematically alter the relative numbers of phytoplankton and bacteria in the water column. Based on this logic, the larger amount of scatter in Fig. 4 compared to Fig. 3 is not surprising. Speculation about bias in the predictions is compromised by the small number of data points.

The consistent bias apparent in the case of systems impacted by river discharge (Table 3) probably reflects an advective throughput of microbial biomass that is not allowed for in the model (Fig. 1). In the model, all living biomass is produced in situ. In addition to being impacted by riverine throughput, the Ria de Aveiro stations in Table 3 are shallow, with mean depths ranging from 0.9 to $2.5 \mathrm{~m}$ (Cunha et al. 2000). However, as noted above, shallowness per se does not appear to create a systematic bias in the predictions. The mean salinity of the inner shelf stations off the mouth of the Yangtze River was 28 psu (Shiah et al. 2001), which implies that $\sim 20 \%$ of the water was river throughput. This undoubtedly accounts for the anomalous autotrophic/heterotrophic microbial biomass ratio at the inner-shelf stations compared to the mid- and outer-shelf stations (Table 1), where mean salinities were 32.6 and 34.2 psu, respectively (Shiah et al. 2001).

Simon et al. (1992) have argued that limnetic systems support more bacterial biomass relative to phytoplank- 
ton biomass than marine systems. The basis for this statement is the fact that in the 6 limnetic and 6 marine systems analyzed by Simon et al. (1992), limnetic systems tended to have a higher concentration of $\mathrm{C}_{\mathrm{HB}}$ at comparable concentrations of chl a. This is not, however, the case in the more recent and extensive studies summarized here (Fig. 5). When chl a concentrations as abscissa are plotted against $\mathrm{C}_{\mathrm{HB}}$ as ordinate and a model II geometric mean regression line is drawn through the data (Fig. 5), only 3 of the 8 freshwater data points lie above the regression line. The scatter in the data in Fig. 5 is much greater $(r=0.79)$ than in Fig. $3(\mathrm{r}=0.91)$, and several of the largest deviations can easily be explained on the basis of temperature effects. The Ross Sea, Antarctica (Asper \& Smith 1999) and Lake Plußsee, Germany (Chróst et al. 1989) studies were carried out at temperatures of 0 and $9^{\circ} \mathrm{C}$, respectively. The concentration of chl a was relatively high in both cases, but at these low temperatures and moderate to high production rates the ratio of $\mathrm{C}_{\mathrm{HB}}$ to phytoplankton carbon is much less than at temperatures of 20 to $25^{\circ} \mathrm{C}$ (Fig. 2). The largest deviations above the regression line were associated with data collected from the Peru upwelling system (Wilkerson et al. 1987) and Strait of Georgia (Harrison et al. 1991). In these 2 cases, temperature $\left(16.8\right.$ and $17.3^{\circ} \mathrm{C}$, respectively) was not responsible for the large positive deviations. Both systems were studied during upwelling/ bloom conditions when the phytoplankton were turning over rapidly. Merely relating $\mathrm{C}_{\mathrm{HB}}$ to phytoplankton biomass does not allow for differences in turnover rates, and in these 2 cases the differences in turnover rates were evidently great enough to cause large deviations from the regression line. The Laws et al. (2000) model does a much better job of predicting $\mathrm{C}_{\mathrm{HB}}$ in these 4 cases (Table 1): in the first two (Ross Sea and Lake Plußsee) because the model explicitly accounts for temperature effects, and in the second two because information was available on photosynthetic rates, which are the product of turnover rate and biomass. Hence, in the case of the Peru upwelling and Strait of Georgia data, it was possible to implement the model in a way that accounted for turnover rate effects.

Finally, it is noteworthy that the slope of the geometric mean regression line in Fig. 4 is 0.78 . This result implies that, other factors being equal, the ratio of $\mathrm{C}_{\mathrm{HB}}$ to chl a decreases with increasing chl a concentration. This conclusion is consistent with earlier studies (Cole et al. 1988, Simon et al. 1992, del Giorgio et al. 1997, Biddanda et al. 2001).

The implication of this analysis is that the underlying cause of the relationships between heterotrophic bacterial biomass and microalgal biomass observed by previous investigators (Pomeroy \& Deibel 1986, Cole et al. 1988, Li et al. 1992, Simon et al. 1992, Legendre \&
Rassoulzadegan 1995, del Giorgio et al. 1997, Gasol et al. 1997, Biddanda et al. 2001) may be the tendency of natural pelagic ecosystems to evolve toward a condition of maximum resiliency. This tendency is believed to be a characteristic of the mature stages of ecological succession (Odum 1969). Because plankton have short generation times, it may also be a characteristic of systems whose behavior is largely controlled by the dynamics of the plankton community. As noted by Hutchinson (1967, p. 376), 'The annual cycle [of the plankton] is thus, in terms of generation time, the equivalent of perhaps up to ten thousand years in the successional history of organisms which are replaced as some forest trees every fifty or one hundred years. However, even if maximum resiliency proves to be a characteristic of many natural planktonic ecosystems, it is certainly possible that other ecological laws influence the behavior of these systems. The first law of thermodynamics is a cornerstone of thermodynamic theory, but not all of thermodynamics can be explained on the basis of conservation of energy.

Systems with unstable steady states are not likely to persist in nature. Furthermore, systems that require a long time to return to their equilibrium configurations following a perturbation are unlikely to be found near their equilibrium point in other than very stable environments. In the simple linear food chain modeled by Cropp \& Gabric (2002), the conditions associated with various selection pressures are easily identified, and the selection pressures suggested by Lotka (1922) and Odum (1983) lead to essentially the same system behavior as does maximum resiliency. Fath et al. (2001) have likewise noted an equivalency of system behavior

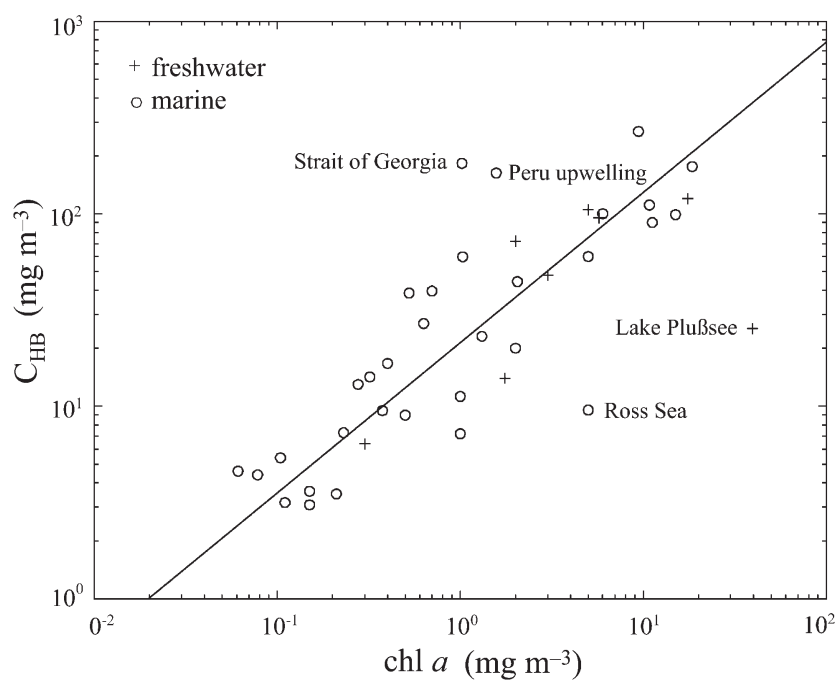

Fig. 5. Chl a versus $\mathrm{C}_{\mathrm{HB}}$ from systems in Table 1 in which information on both was available. The straight line is a geometric mean model II regression line 
governed by seemingly disparate ecological goal functions. In more complex systems, application of thermodynamic analogues as selection pressures to determine ecosystem behavior has met with mixed success. Månsson \& McGlade (1993), for example, point out that the flows of carbon in 6 marine ecosystems studied by Baird et al. (1991), 'were contrary to what Odum has suggested, in that the aggregate amount of cycling was an indication not of maturity but rather of the type of dynamics and levels of stress.' On the other hand, Cropp \& Gabric (2002) observe that in some cases thermodynamic approaches have met with considerable success in estimating parameters to describe real ecosystems (Jørgensen \& Straskraba 2000).

Is it possible that very similar predictions concerning the partitioning of microbial biomass could emerge from the model in Fig. 1 if a criterion other than maximum resiliency were applied? To explore this hypothesis, I simply tried to average the ratio of heterotrophic bacterial biomass to phytoplankton biomass $\left(\mathrm{C}_{\mathrm{HB}}: \mathrm{C}_{\mathrm{P}}\right)$ over all stable steady states at various temperatures and allochthonous nutrient loading rates and compared the average $\mathrm{C}_{\mathrm{HB}}: \mathrm{C}_{\mathrm{P}}$ ratio to the ratio associated with maximum resiliency. The result of this exercise showed that at high temperatures (e.g. $25^{\circ} \mathrm{C}$ ) the ratio associated with maximum resiliency was little different from the ratio averaged over all stable steady states. This conclusion was especially true under oligotrophic conditions. Under eutrophic conditions and at high temperatures, the discrepancy was at most 10 to $20 \%$. The discrepancy became much greater at low temperatures (e.g. $5^{\circ} \mathrm{C}$ ). The model (Fig. 2) predicts a range of roughly 2 orders of magnitude in the $\mathrm{C}_{\mathrm{HB}}: \mathrm{C}_{\mathrm{P}}$ ratio at $5^{\circ} \mathrm{C}$, with the lowest ratios under eutrophic conditions and the highest under oligotrophic conditions. If the ratio is simply averaged over all stable steady states at a given allochthonous nutrient loading rate, the average ratio ranges between roughly 0.6 and 0.7 . Since the predictions of the model are in good agreement with field data at low temperatures over a wide range of $C_{P}$ (e.g. Crooked Lake, Antarctica, and Lake Plußsee, Table 1), I conclude that applying the criterion of maximum resiliency considerably improves the predictive ability of the model as opposed to simply requiring that the steady state be stable.

I agree with Patten (1993) that the important thrust of Odum's (1983) work was his search for laws that govern the organization of ecosystems. Maximum resiliency may well be one of those laws. Indeed, Odum (1969) concluded more than 30 yr ago that ecological succession leads to mature stages characterized by good resistance to external perturbations. As noted by Jørgensen \& Straskraba (2000), ecological systems are flexible. This property will need to be taken into consideration if models are to reliably predict the behavior of ecosystems in response to changing forcing functions. Predicting the response of both aquatic and terrestrial ecosystems to environmental change (Mackenzie 1998) will ultimately require awareness and recognition of the laws that govern the response of ecosystems to their environment. Maximum resiliency may be a useful construct for pelagic food webs.

Acknowledgements. This work was supported by National Science Foundation grant OCE-97-25966. I am indebted to 3 anonymous reviewers for their constructive comments on this paper. This is SOEST contribution number 6149.

\section{LITERATURE CITED}

Asper VL, Smith WO (1999) Particle fluxes during austral spring and summer in the southern Ross Sea (Antarctica). J Geophys Res 104:5345-5360

Baird D, McGlade JM, Ulanowicz R (1991) The comparative ecology of six marine ecosystems. Phil Trans R Soc Lond B $333: 15-29$

Bannister TT (1974) A general theory of steady state phytoplankton growth in a nutrient saturated mixed layer. Limnol Oceanogr 19:13-30

Biddanda B, Ogdahl M, Cotner J (2001) Dominance of bacterial metabolism in oligotrophic relative to eutrophic waters. Limnol Oceanogr 46:730-739

Blight SP, Bentley TL, Lefevre D, Robinson C, Rodrigues R, Rowlands J, Williams PJleB (1995) Phasing of autotrophic and heterotrophic plankton metabolism in a temperate coastal ecosystem. Mar Ecol Prog Ser 128:61-75

Bode A, Barquero S, Varela M, Braun JG, de Armas D (2001) Pelagic bacteria and phytoplankton in oceanic waters near the Canary Islands in summer. Mar Ecol Prog Ser 209:1-17

Butler HG, Edworthy MG, Ellis-Evans JC (2000) Temporal plankton dynamics in an oligotrophic maritime Antarctic lake. Freshw Biol 43:215-230

Carlson CA, Ducklow HW (1996) Growth of bacterioplankton and consumption of dissolved organic carbon in the Sargasso Sea. Aquat Microb Ecol 10:69-85

Carlson CA, Ducklow HW, Hansell DA, Smith WO Jr (1998) Organic carbon partitioning during spring phytoplankton blooms in the Ross Sea polynya and the Sargasso Sea. Limnol Oceanogr 43:375-386

Chan AT (1980) Comparative physiological study of marine diatoms and dinoflagellates in relation to irradiance and cell size. II. Relationship between photosynthesis, growth, and carbon/chlorophyll a ratio. J Phycol 16:428-432

Cho BC, Azam F (1990) Biogeochemical significance of bacterial biomass in the ocean's euphotic zone. Mar Ecol Prog Ser 63:253-259

Chróst RJ, Münster U, Rai H, Albrecht D, Witzel PK, Overbeck J (1989) Photosynthetic production and exoenzymatic degradation of organic matter in the euphotic zone of a eutrophic lake. J Plankton Res 11:223-242

Chrzanowski TH, Grover JP (2001) Effects of mineral nutrients on the growth of bacterio- and phytoplankton in two southern reservoirs. Limnol Oceanogr 46:1319-1330

Cole JJ, Findlay S, Pace ML (1988) Bacterial production in fresh and saltwater ecosystems: a cross-system overview. Mar Ecol Prog Ser 43:1-10

Cotner JB, Biddanda BA (2002) Small players, large role: 
microbial influence on biogeochemical processes in pelagic aquatic ecosystems. Ecosystems 5:105-121

Coveney MF, Wetzel RG (1995) Biomass, production, and specific growth rate of bacterioplankton and coupling to phytoplankton in an oligotrophic lake. Limnol Oceanogr 40:1187-1200

Cropp R, Gabric A (2002) Ecosystem adaptation: Do ecosystems maximize resilience? Ecology 83:2019-2026

Cunha MA, Almeida MA, Alcantara F (2000) Patterns of ectoenzymatic and heterotrophic bacterial activities along a salinity gradient in a shallow tidal estuary. Mar Ecol Prog Ser 204:1-12

del Giorgio P, Cole JJ, Cimbleris A (1997) Respiration rates in bacteria exceed phytoplankton production in unproductive aquatic systems. Nature 385: 148-151

DiTullio GR, Smith WO Jr (1996) Spatial patterns in phytoplankton biomass and pigment distributions in the Ross Sea. J Geophys Res 101:18467-18477

Donachie SP, Kinzie RA III, Bidigare RR, Sadler DW, Karl DM (1999) Lake Kauhako, Molokai, Hawaii: biological and chemical aspects of a morpho-ectogenic meromictic lake. Aquat Microb Ecol 19:93-103

Downs J (1989) Export of production in oceanic systems: information from phaeopigment carbon and nitrogen analyses. PhD dissertation, University of Washington, Seattle, WA

Ducklow HW, Kirchman DL, Quinby HL, Carlson CA, Dam HG (1993) Stocks and dynamics of bacterioplankton carbon during the spring bloom in the eastern North Atlantic Ocean. Deep-Sea Res 40:245-263

Ducklow HW, Quinby HL, Carlson CA (1995) Bacterioplankton dynamics in the Equatorial Pacific during the $1992 \mathrm{El}$ Niño. Deep-Sea Res 42:621-638

Ducklow HW, Smith DC, Campbell L, Landry MR, Quinby HL, Steward G, Azam F (2000) Heterotrophic bacterioplankton distributions in the Arabian Sea: basinwide response to high primary productivity. Deep-Sea Res 48: 1387-1422

Fath BD, Patten BC, Choi JS (2001) Complementarity of ecological goal functions. J Theor Biol 208:493-506

Fenchel T (1987) Ecology-potentials and limitations. In: Kinne O (ed) Excellence in ecology, Book 1. Ecology Institute, Oldendorf/Luhe

Fuhrman JA, Eppley RW, Hagström Å, Azam F (1985) Diel variations in bacterioplankton, phytoplankton, and related parameters in the Southern California Bight. Mar Ecol Prog Ser 27:9-20

Fukuda R, Ogawa H, Nagata T, Koike I (1998) Direct determination of carbon and nitrogen contents of natural bacterial assemblages in marine environments. Appl Environ Microbiol 64:3352-3358

Gasol JM, del Giorgio PA, Duarte CM (1997) Biomass distribution in marine planktonic communities. Limnol Oceanogr 42:1353-1363

Harrison PJ, Clifford PJ, Cochlan WP, Yin K, St John MA, Thompson PA, Sibbald MJ, Albright LJ (1991) Nutrient and plankton dynamics in the Fraser River plume, Strait of Georgia, British Columbia. Mar Ecol Prog Ser 70:291-304

Hessen DO (1985) The relation between bacterial carbon and dissolved humic compounds in oligotrophic lakes. FEMS Microbiol Ecol 31:215-223

Hoch MP, Kirchman DL (1993) Seasonal and inter-annual variability in bacterial production and biomass in a temperate estuary. Mar Ecol Prog Ser 98:283-295

Hutchinson GE (1967) A treatise on limnology, Vol II. Wiley, New York

Jørgensen SE, Straskraba M (2000) Ecosystems as cybernetic systems. In: Jørgensen SE, Müller F (eds) Handbook of ecosystem theories and management. Lewis Publishers, Boca Raton, FL, p 249-264

Karl DM, Dobbs FC (1998) Molecular approaches to microbial biomass estimation in the sea. In: Cooksey KE (ed) Molecular approaches to the study of the ocean. Chapman \& Hall, New York, p 29-89

Kirchman DL, Keil RG, Simon M, Welschmeyer NA (1993) Biomass and production of heterotrophic bacterioplankton in the oceanic subarctic Pacific. Deep-Sea Res 40:967-988

Kisand V, Tammert H (2000) Bacterioplankton strategies for leucine and glucose uptake after a cyanobacterial bloom in an eutrophic shallow lake. Soil Biol Biochem 32: 1965-1972

Kormas KA, Kapiris K, Thessalou-Legaki M, Nicolaidou A (1998) Quantitative relationships between phytoplankton, bacteria and protests in an Aegean semi-enclosed embayment (Maliakos Gulf, Greece). Aquat Microb Ecol 15: 255-264

Laws EA, Falkowski PG, Smith WO Jr, Ducklow H, McCarthy JJ (2000) Temperture effects on export production in the open ocean. Global Biogeochem Cycles 14:1231-1246

Laybourn-Parry J, Marchant HJ, Brown PE (1992) Seasonal cycle of the microbial plankton in Crooked Lake, Antarctica. Polar Biol 12:411-416

Legendre L, Rassoulzadegan F (1995) Plankton and nutrient dynamics in marine waters. Ophelia 41:153-172

Li WKW, Dickie PM, Irwin BD, Wood AM (1992) Biomass of bacteria, cyanobacteria, prochlorophytes and photosynthetic eukaryotes in the Sargasso Sea. Deep-Sea Res 39: $501-519$

Lotka A J (1922) Contribution to the energetics of evolution. Proc Natl Acad Sci USA 8:147-151

Mackenzie FT (1998) Our changing planet, 2nd edn. Prentice Hall, Englewood Cliffs, NJ

Månsson BÅ, McGlade JM (1993) Ecology, thermodynamics, and H T Odum's conjectures. Oecologia 93:582-596

May RM (1974) Stability and complexity in model ecosystems, 2nd edn. Princeton University Press, Princeton, NJ

Marra J (2002) Approaches to the measurement of plankton production In: Williams PJleB, Thomas DN, Reynolds CS (eds) Phytoplankton productivity: carbon assimilation in marine and freshwater ecosystems. Blackwell Scientific Publications, Oxford, p 78-108

Murray JW, Downs JN, Strom S, Wei CL, Jannasch HW (1989) Nutrient assimilation, export production, and ${ }^{234} \mathrm{Th}$ scavenging in the eastern equatorial Pacific. Deep-Sea Res 36: 1471-1489

Odum E (1969) The strategy of ecosystem development. Science 164:262-270

Odum H (1983) Systems ecology: an introduction. Wiley, New York

Panzenböck M, Möbes-Hansen B, Albert R, Herndl GJ (2000) Dynamics of phyto- and bacterioplankton in a high Arctic lake on Fraqnz Joseph Land archipelago. Aquat Microb Ecol 21:265-273

Patten BC (1993) Toward a more holistic ecology, and science: the contribution of H T Odum. Oecologia 93: 597-602

Pedrós-Alió C, Brock TD (1982) Assessing biomass and production of bacteria in eutrophic Lake Mendota, Wisconsin. Appl Environ Microbiol 44:203-218

Pomeroy LR, Deibel D (1986) Temperature regulation of bacterial activity during the spring bloom in Newfoundland coastal waters. Science 233:359-361

Reitner B, Herzig A, Herndl GJ (1997) Microbial activity under the ice cover of the shallow Neusiedler See (Austria, Central Europe). Hydrobiologia 357:173-184 
Revilla M, Iriarte A, Madariaga I, Orive E (2000) Bacterial and phytoplankton dynamics along a trophic gradient in a shallow temperate estuary. Estuar Coast Shelf Sci 50: 297-313

Richardson K, Nielsen TG, Pedersen FB, Heilmann JP, Løkkegaard B, Kaas H (1998) Spatial heterogeneity in the structure of the planktonic food web in the North Sea. Mar Ecol Prog Ser 168:197-211

Rodríguez F, Fernández E, Head RN, Harbour DS, Bratbak G, Heldal M, Harris RP (2000) Temporal variability of viruses, bacteria, phytoplankton and zooplankton in the western English Channel off Plymouth. J Mar Biol Assoc UK 80: 575-586

Sakshaug E, Holm-Hansen O (1986) Photoadaptation in Antarctic phytoplankton: variations in growth rate, chemical composition and P versus I curves. J Plankton Res 8: 459-473

Scheffer M (1999) The effect of aquatic vegetation on turbidity; how important are the filter feeders? Hydrobiologia 408/409:307-316

Scheffer M (2001) Alternative attractors of shallow lakes. Sci World J 1:254-263

Scheffer M, Rinaldi S, Kuznetsov YA (2000) Effects of fish on plankton dynamics: a theoretical analysis. Can J Fish Aquat Sci 57:1208-1219

Shiah FK, Chen TY, Gong GC, Chen CC, Chiang KP, Hung JJ (2001) Differential coupling of bacterial and primary production in mesotrophic and oligotrophic systems of the East China Sea. Aquat Microb Ecol 23:273-282

Shuter B (1979) A model of physiological adaptation in unicellular algae. J Theor Biol 78:519-552

Sime-Ngando T, Gosselin M, Roy S, Chanut JP (1995) Significance of planktonic ciliated protozoa in the lower St Lawrence estuary: comparison with bacterial, phytoplankton, and particulate organic carbon. Aquat Microb Ecol 9: 243-258

Simon M, Cho BC, Azam F (1992) Significance of bacterial biomass in lakes and the ocean: comparison to phyto-

Editorial responsibility: Fereidoun Rassoulzadegan, Villefranche-sur-Mer, France plankton biomass and biogeochemical implications. Mar Ecol Prog Ser 86:103-110

Simon M, Tilzer MM, Müller H (1998) Bacterioplankton dynamics in a large mesotrophic lake: I. Abundance, production and growth control. Arch Hydrobiol 143:385-407

Smith WO Jr, Nelson DM, DiTullio GR, Leventer AR (1996) Temporal and spatial patterns in the Ross Sea: phytoplankton biomass, elemental composition, productivity and growth rates. J Geophys Res 101:18455-18465

Sommaruga R (1995) Microbial and classical food webs: a visit to a hypertrophic lake. FEMS Microbiol Ecol 17:257-270

Sommaruga R, Psenner R (1995) Trophic interactions within the microbial food web in Piburger See (Austria). Arch Hydrobiol 132:257-278

Sorokin YI, Kogelschatz JE (1979) Analysis of heterotrophic microplankton in an upwelling area. Hydrobiologia 66: 195-208

Steemann Nielsen E (1952) The use of radio-active carbon $\left(\mathrm{C}^{14}\right)$ for measuring organic production in the sea. J Cons Int Explor Mer 16:117-140

Vadstein O, Jensen A, Olsen Y, Reinersten H (1988) Growth and phosphorus status of limnetic phytoplankton and bacteria. Limnol Oceanogr 33:489-503

Vörös L, Balogh KV, Herodek S (1996) Microbial food web in a large shallow lake (Lake Balaton, Hungary). Hydrobiologia 339:57-65

Wilkerson FP, Dugdale RC, Barber RT (1987) Effects of El Niño on new, regenerated, and total production in eastern boundary upwelling systems. J Geophys Res 92: 14347-14353

Yager P (1996) The microbial fate of carbon in high-latitude seas: Impact of the microbial loop on oceanic uptake of $\mathrm{CO}_{2}$. PhD dissertation, University of Washington, Seattle, WA

Zdanowski MK Figueiras FG (1997) Relationships between the abundance of bacteria and other biota and the hydrographic variability in the Ría de Vigo, Spain. Mar Ecol Prog Ser 147:257-267

Submitted: June 5, 2002; Accepted: November 4, 2002 Proofs received from author(s): April 24, 2003 